УДК 7.033.2...1

ББК 85.11

DOI:10.18688/aa155-2-20

Livia Bevilacqua

\title{
Family Inheritance: Classical Antiquities Reused and Displayed in Byzantine Cities
}

The reuse and display of ancient statuary and spolia in the Byzantine cities in Late Antiquity has been studied extensively in the last decades. Therefore, in this few pages I will not undertake a reassessment of the question in its general terms, nor comment upon a very well known phenomenon ${ }^{1}$. Focusing on the realm of figural spolia in the Byzantine world, I wish instead to observe and trace the occurrence and survival of a classical iconographic subject - the myth of Heracles - which appears on a peculiar urban setting: the city gates of Byzantine Asia Minor.

I will endeavour to trace the occurrence of this iconographic theme by describing a few examples, and I will start from the very heart of Anatolia. In fact, one relevant case appears to be particularly interesting in this respect, namely the Byzantine citadel of Ankara. In the seventh century, the once prosperous Roman city of Ancyra undergoes several sacks by the hands of the Persians, first, and then of the Arabs. Large areas of the city are set on fire, and thence abandoned. Following this catastrophic events, the city is partially restored and rebuilt making use of the materials quarried from the Roman monuments. Like almost all of the Late Antique cities, in this context of turmoil, the city receives a new fortification ${ }^{2}$. The fortified area is radically reduced in extension - compared to the area of the Roman settlement - and removed to the top of the steep slopes of one of the city's hills, the one that today has the Turkish name of Altındağ ("Golden Mountain"). When seen from the distance, the new citadel of Byzantine Ankara would thus appear impregnable, thanks to its string of pentagonal towers, projecting from the walls in resemblance of ship's prows. The main gate itself would not be spottable at first glance, since it was hidden behind a barbican with an elbow-shaped entrance system. The latter is now called "Zindan Kapı", "Dungeon gate" in Turkish. Nonetheless, even in a curtain of walls built almost entirely out of materials quarried from ancient, abandoned

\footnotetext{
Secondary literature on the topic of spolia and their reception is huge. I will mention here only a few general reference texts, most of them limited to the Byzantine world. Several of the authors cited have tackled the topic more than once; I am citing their first relevant approach to the matter $[50,33,12,7,35,43$, $9,11,1,22,18,29,44,8,38,4,15,23,41,37,47]$. Nevertheless, studies on figural spolia in their secondary setting in the Byzantine art and architecture have not been accurately researched yet, especially as far as spolia in fortifications are concerned. I dwelled on this topic myself in the Proceedings of the Third Symposium on "Actual Problems of Theory and History of Art" [6]. The present article includes some remarks that are being integrated in the context of a wider research project on figural spolia in Byzantium. Specifically, I have carried out my research on the city walls of Ankara thanks to a TÜBITAK-BIDDEB Research Fellowship at the University of Istanbul.

2 On the history of the Roman settlement of Ancyra, see [24]. As for the Byzantine phase, see [17, 40, $5,3,46]$.
} 
buildings, the segment hosting the main gate was visually highlighted through a set of elements of a different nature: albeit spolia, they bear some carefully arranged decoration and a row of human figures.

The seventh-century enceinte is approximately rectangular in shape (Fig. 1). Its main entrance is in the middle of the south side, facing the most gentle and accessible slope of the hill. The southern and western extension to the fortress is an addition that has been dated to the $9^{\text {th }}$ century, on the basis of epigraphic evidence $[19,20]$, and I will not consider that one on this occasion, although it is still awaiting a more thorough and comprehensive study.

The decoration that I am going to describe is displayed on the inner circle, the "İç Kale", on the outer wall of the aforementioned projecting barbican (Ill. 31). Three levels or registers of decoration can be seen: the central, main visual line is provided by a row of white marble or limestone slabs, probably pieces of a balustrade, or socle, of some dismissed building, rather than altars. Only the

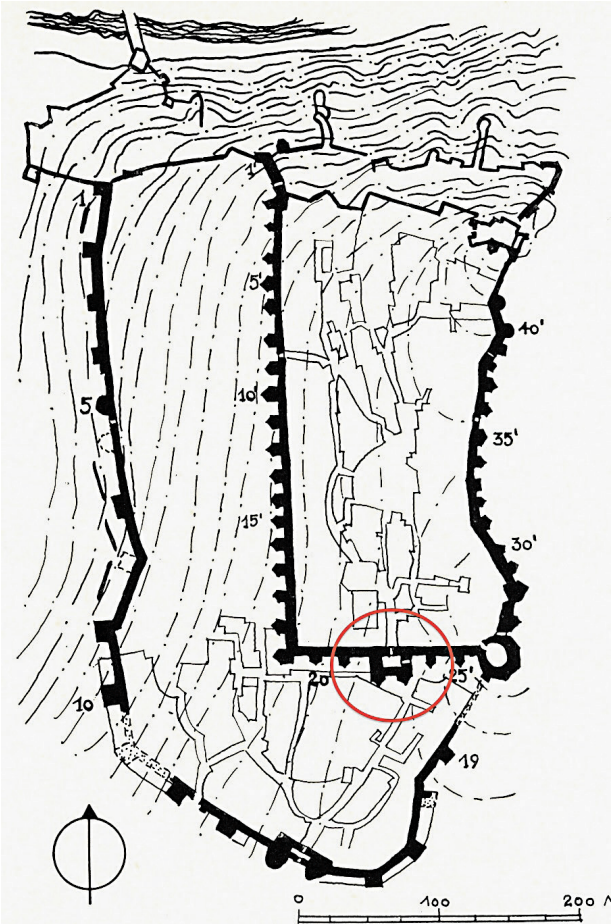

Fig.1: Ankara, the Byzantine citadel, map (after Restle M. s.v. Ankyra. Reallexikon zur byzantinischen Kunst, I, Stuttgart, Hiersemann, 1966). one occupying the central position is most likely either an altar or a funerary stele. It is decorated with a garland, a rosette, and two protomes (bucrania), along with two palm-shaped acroteria, common in Roman tombstones' ornament.

The upper register's decorative details are scarcely visible today: three rectangular blocks, of a bluish marble, are arranged alternately to white blocks. They contrast with one another, not only because of their colour, but also because the former used to bear figural reliefs, now almost completely worn out. Thanks to some early nineteenth-century photographs, such as the pictures taken by Sebah and Joaillier, dating back to before 1933 and published in Mamboury's Guide Touristique d'Ankara [32], the nature of this upper level of decoration can be somehow established. The third marble block from the left clearly reveals a scene, for which the Photographic Archive of the German Archaeological Institute in Istanbul preserves a detail: while it is catalogued as a "Battle scene" in the DAI database, a winged figure in the centre would rather point to a triumphal scene ${ }^{3}$.

The third, and lower register of decoration displays a series of most interesting pieces, all in a row. To begin with, a fragment of an inscription can be read: in consideration of its shape and of the quality of its ornamentation, it must have been recovered from the stoa, the via colonnata of Roman Ancyra, although, reportedly, it cannot be integrated into the text of

\footnotetext{
3 A similar arrangement of alternating reused reliefs and smooth conches can be seen on the Late antique walls of Aphrodisias [37].
} 
the other epigraphic findings of that excavated area. It is tempting indeed to read here "... $\Upsilon$ P $\Omega$ MA..."4.

There follow four little herms, lying on their sides, whose heads have been either broken or intentionally removed, it is impossible to say when. Who do these reliefs portray? Only Guillaume de Jerphanion has attempted to explain their subject: he has described them as "priapes couchés", "reclined Priapi", which might have had an apotropaic function. It is likely that Jerphanion, back in 1928, was not able to get close enough to the curtain, and that he could not observe the reliefs carefully, otherwise he would not have misidentified this figures. Alas, Jerphanion's words have been repeated up until the most recent studies. Seen upright, in reality, the herms introduce themselves plainly (Ill. 32): a man is holding a lion's head with his left hand, while with his right he holds to his chest the corners of a cloak, which is in fact a lion's skin, since we can easily recognise the animal's paws. One cannot doubt the fact that Heracles with the Nemean Lion has been portrayed here, although this is certainly not the most common iconography of the popular demi-god. If, on the one hand, we are used to seeing him standing, naked, holding a club and supporting the lion's skin with his arm, on the other hand, herms such as the ones found in Herculaneum show the hero wearing such skin as a mantle, but without the lion's head in his hand [42]. To my knowledge, there is only one parallel to this, and it is, again, in Asia Minor.

In fact, Ephesus, too, in Late Antiquity, experiences the same contraction as other Anatolian cities. In the $5^{\text {th }}$ century, the passage between the areas of the upper agora and the lower market area (the latter, apparently, still in use at the time) is marked by the so-called "Gate of Heracles" [14]. Interestingly, this late antique archway had been built out of spolia, including two herm-like jambs with the effigy of our hero. Except for the fact that the Ephesian sculptures are larger in scale than the Ankara ones, the two examples are absolutely overlapping. I think we should ask ourselves whether the display of the effigy of Heracles on these two late antique city gates is to be considered mere chance or if it might have been deliberate.

Two more major cases of display of the (in one case symbolic) image of Heracles need to be recalled in this respect, both of them in the very capital city of the Byzantine empire, Constantinople: the triumphal archway of the Forum Tauri (the Theodosian cattle market square) was precisely composed of a set of columns resembling Heracles' club: the hand of the hero was holding them from the top, thus suggesting his real gigantic presence. There are only broken bits left today of the Theodosian Forum, but the reconstruction drawn by Rudolf Naumann provides a clear idea of it [36].

It is true that there was a cross carved on the base of one of the columns of the Theodosian arch, but the Christian sign is here a minor one, compared to the massive predominance of the Herculean symbol, and may even be a later addition. It is well known how much Theodosius' imperial ideology - despite his laws against the idols - was entrusted to the symbolic image of the demi-god 6 .

\footnotetext{
$4 \quad$ I was not able to see de visu the findings from the stoa, therefore my considerations are based on the photographic material available. However, I incline to think that the epigraphic evidence of our fragment is consistent to the set of remaining fragments of that excavation area. For a correct reading of the text, we shall wait for the complete publication of all the findings [48].

[10, p. 150]. On the relationship of this French scholar with Turkey, and Ankara in particular, see [16]. On the Theodosian dynasty, see, most recently, [39].
} 
One might argue that the Theodosian columns were by no means a reuse, and no city gate proper. However, the recovery was there ideological indeed, and - being a triumphal arch - that of the Forum Tauri conveyed the same meanings as the gateways along the city walls, marking different steps of the same triumphal way of the victorious emperor to the city. As it is well known, and as it has been widely demonstrated (by Paul Magdalino and Cyril Mango among others ${ }^{7}$ ), the starting point of such triumphal way to central Constantinople, throughout the Byzantine millennium (or at least until the $12^{\text {th }}$ century), was the Golden Gate. Here, at an unspecified, later, date - either Middle or Late Byzantine - an outer wall was added, which was adorned by means of a set of twelve reliefs. They had already disappeared by the end of the $17^{\text {th }}$ century, but, as we learn from earlier descriptions, along with other mythological characters such as Endymion, Selene, Cupid, Pegasus, a selection of the Twelve Labours of Heracles was also visible, carved on marble slabs recovered from earlier monuments ${ }^{8}$. In the context of a wider iconographic program, even in this later case, the scenes depicting Heracles might have been intentionally chosen to adorn a key point of the city, one especially striking the Byzantine imagery.

In this respect, the case of Ankara preserves its crucial importance, being - to my knowledge - the best preserved example in Byzantine Anatolia, although the landscape of Altındağ has changed dramatically in less than a century.

The case of the Forum of Theodosius, as recalled, is emblematic, in that we know exactly its patron and the ideology which lays behind it. May we infer that the Herculean iconography might have been deliberately chosen in Ankara, as well? This latter question brings about a major problem: the date of the building of the Upper fortress. Very few elements can be effectively taken into account to this purpose. As I briefly outlined in the beginning, the dating of the walls within the $7^{\text {th }}$ century is coherent with a refortification of the city against the Persian and Arab invasions. Most of the scholars (Restle and Foss in primis [40, 17]) have placed the walls into the reign of Constans II (641-668), after the capture of the city by Muawiya, and in the context of the reorganization of the eastern military districts of the empire. Archibald Dunn has offered a different hypothesis, on the basis of the resemblance of Ankara's inner castle with sixth-century Balkan fortifications, such as Salona: the "sawlike", pentagonal-towered system has been applied to both Salona and Ankara, following the directions of the "Anonymous" sixth-century treatise on the construction of a city [13]. The Balkans were still part of the Byzantine empire up to the reign of Heraclius (610-641), and the biographers of this emperor report that the champion of the Christianity against the Persians, was also a keen expert in military art [cfr. 25]. Moreover, the entrance system of the bastion projecting from the south wall, recalls the "gamma-shaped" gates recommended by

\footnotetext{
The two scholars have devoted a number of major studies to the topography of ancient Constantinople, and specifically to this problem: [30, recently $31 ; 34]$.

8 On the basis of the position of the frames (still in situ), it is possible to envision the arrangement of the reliefs on two rows, placed symmetrically on the two sides of the outer gate. A few fragments only remain today, which were recovered during the excavations carried out in the 1920s [28], and which are currently on display in the Istanbul Archaeological Museum. The reliefs had been described by the British ambassador to the Porte, Sir Thomas Roe, in early $17^{\text {th }}$ century [49, pp. 386-387], before they disappeared by the end of the seventeenth century. For an overview of the Theodosian walls of Constantinople, see at least $[26,2]$. On the outer addition to the Golden Gate, and its debated chronology, see also [21, 34].
} 
a number of ancient military treatises on the building of a military camp ${ }^{9}$, which Heraclius surely knew about. The illustrations preserved (such as the one in cod. Vat. gr. 1164, fol. 236v, dating to ca. 1020) illustrate later manuscripts, but the idea goes far back into antiquity. It must be taken into account that the primary sources are generous as far as the reign of Heraclius is concerned [25], but not so much so when it comes to the reign of Constans II, thus making a judgement on the reign, and ideological inspiration, of the latter very hard. Nevertheless, I think that the presence of Heracles' figures on Ankara's gate might further support Dunn's idea. Mythological elements have been connected in many ways to the artistic production of the time of Heraclius - I will just mention, but not comment upon, the complicated problem of the Silver "David" Plates [27]. This problem surely deserves a deeper investigation.

Be it as it may, as they used to be throughout the Byzantine era, the Herculean reliefs of the Zindan Kapi still, represent, both in their position and in their meaning, what might be regarded as a "family inheritance", entrusted to the generations to come. The walls of the Byzantine citadel mark today the space of a playground for the children of Ankara - if not a construction site [45] - and even in this "tertiary" function the figural spolia immured in the curtain represent a major sign of the legacy of antiquity that still awaits to find its correct place in history.

Title. Family Inheritance: Classical Antiquities Reused and Displayed in Byzantine Cities.

Author. Livia Bevilacqua - Ph. D., Research Fellow. Ca' Foscari University of Venice, Dorsoduro 3484/D, 30123 Venezia, Italy. liviabevilacqua@gmail.com

Abstract. A small group of gates of Byzantine city walls were decorated with reused, ancient figural sculpture, including the figure of Heracles. In some cases, such as the herms arranged horizontally on the main gate to the citadel of Ankara, this subject had not been identified before. Along with providing a detailed analysis of the decoration of the Zindan Kap1 at Ankara, this paper traces the occurrence of the same iconographical subject, in similar architectural and urban contexts. Other examples considered as a comparison are the "Gates of Heracles" in Ephesos, the "Golden Gate" in Constantinople and the arch in the Theodosian Forum in the same capital city.

Keywords: Byzantine architecture; city walls; fortification; Spolia; Anatolia; Ankara; Ephesus; Constantinople.

Название статьи. Фамильное наследство: античные артефакты, вторично используемые в византийских городах.

Сведения об авторе. Бевилаква Ливия - Ph. D., научный сотрудник. Университет Ка'Фоскари, Dorsoduro 3484/D, Венеция, Италия, 30123. liviabevilacqua@gmail.com

Аннотация. В ряде случаев византийские городские ворота украшали античные скульптуры, в том числе фигуры Геракла. Некоторые из этих памятников до сих пор не были исследованы, среди них, например, помещенные в горизонтально установленных гермах скульптуры главных ворот цитадели Анкары. В данной статье автор, наряду с детальным анализом декора башни-темницы (Зиндан Капи) в Анкаре, прослеживает устойчивое повторение иконографического сюжета в других памятниках и выделяет некоторые детали, позволяющие установить, чем был предопределен выбор изображения данного мифологического героя в такого рода сооружениях. В качестве сравнительного ряда для исследования привлекаются «Ворота Геракла» в Эфесе, «Золотые ворота» и Форум Феодосия в Константинополе.

Ключевые слова: византийская архитектура; городские стены; крепостные сооружения; сполии; Анатолия; Анкара; Эфес; Константинополь.

\section{References}

1. Poeschke J. (ed.). Antike Spolien in der Architektur des Mittelalters und der Renaissance. Munich, Hirmer Publ., 1996. 368 p. (in German). 
2. Asutay-Effenberger N. Die Landmauer von Konstantinopel-İstanbul: historisch-topographische und baugeschichtliche Untersuchungen. Berlin - New York, Millenium Studien Publ., 18, 2007. 271 p. (in German).

3. Barsanti C. s.v. Ankara. Enciclopedia dell'arte medievale II. Roma, Istituto della Enciclopedia Italiana Publ., 1991, pp. 33-35 (in Italian).

4. Bassett S. E. The urban image of late antique Constantinople. Cambridge, Cambridge University Press Publ., 2004. $291 \mathrm{p}$.

5. Belke K. s.v. Ankara, Galatia and Lykaonen. Tabula Imperii Byzantini, 4. Wien, Verlag der Österreichischen Akademie der Wissenschaften Publ., 1984, pp. 126-130 (in German).

6. Bevilacqua L. Displaying the Past in Byzantium. Figural Spolia on the City Gates of Nicaea (13th c.). Actual Problems of Theory and History of Art III. Collection of Articles, Proceedings of the Third Annual Conference of young specialists in history and theory of art (St. Petersburg State University, Faculty of History, 31 October-4 November 2012), 2013, vol. 3, pp. 145-150.

7. Mullett M.; Scott R. (eds.) Byzantium and the Classical Tradition. University of Birmingham, thirteenth Spring Symposium of Byzantine Studies 1979. Birmingham, Centre for Byzantine Studies Publ., 1981. 249 p.

8. Coats-Stevens R. Attitudes to Spolia in some late antique Texts. Theory and Practice in Late Antique Archaeology. Leiden, Brill Publ., 2003, pp. 341-358.

9. Cutler A. s.v. Spolia. The Oxford Dictionary of Byzantium III, New York - Oxford, Oxford University Press Publ., 1991, p. 1939.

10. Jerphanion G. Byzantine citadel of Angora. Mélanges d’archéologie anatolienne. Monuments préhelléniques, gréco-romains, byzantins et musulmans de Pont, de Cappadoce et de Galatie (Mélanges de l'université Saint-Joseph, 13, I-II). Beyrouth, Imprimerie Catholique Publ., 1928, pp. 144-227 (in Italian).

11. De Lachenal L. Spolia: uso e reimpiego dell'antico dal III al XIV secolo. Milano, Longanesi Publ., 1995. 442 p. (in Italian).

12. Deichmann F. W. Die Spolien in der spätantiken Architektur. München, Verlag der Bayerischen Akad. der Wiss. Publ., 1975. 101 p. (in German).

13. Dunn A. Heraclius "Reconstruction of Cities" and Their Sixth-Century Balkan Antecedents. Acta XIII Congressus Internationalis Archaeologiae Christianae, II. Studi di Antichità Cristiana pubblicati a cura del Pontificio Istituto di Archeologia Cristiana, 54. Roma; Split, Città del Vaticano, 1998, vol. 87-89, pp. 795-806.

14. Daim F.; Ladstätter S. (eds.). Ephesos in byzantinischer Zeit. Mainz, Verlag des Römisch-Germanischen Zentralmuseums Publ., 2011. 254 p. (in German).

15. Esch A. Wiederverwendung von Antike im Mittelalter. Die Sicht des Archäologen und die Sicht des Historikers. Berlin, de Gruyter Publ., 2005. 88 p. (in German).

16. Eyice S. P. Guillaume de Jerphanion ve Ankara Kalesi. Ankara Dergisi, 2, 1993, no. 5, pp. 9-31.

17. Foss C. Late Antique and Byzantine Ankara. Dumbarton Oaks Papers, 1977, no. 31, pp. $27-87$.

18. Greenhalgh M. Spolia in fortifications: Turkey, Syria and North Africa. Ideologie e pratiche del reimpiego nell'Alto Medioevo, Atti della XLVI Settimana CISAM, II. Spoleto, la Sede del Centro Publ., 1999, pp. 785-932 (in Italian).

19. Grégoire H. Inscriptions historiques byzantines. Byzantion, 1927-1928, no. 4, pp. 437-468.

20. Grégoire H.Michael III and Basil the Macedonian in the inscriptions of Ancyra. Byzantion, 1929-1930, no. 5, pp. 327-346 (in French).

21. Guberti Bassett S. John V Palaiologos and the Golden Gate in Constantinople. To Hellenikon. Studies in Honor of Speros Vryonis Jr., I. Hellenic Antiquity and Byzantium. New Rochelle NY, Artistide D. Caratzas Publ., 1993, pp. 117-133.

22. James L. "Pray not to fall into temptation and be on your guard": Antique Statues in Christian Constantinople. Gesta, 1996, no. 35, pp. 12-20.

23. Johnson M. J.; Kiilerich B. Antiquus et modernus: Spolia in Medieval Art - Western, Byzantine and Islamic. Medioevo: il tempo degli antichi, Atti del Convegno internazionale di studi Parma, 24-28 settembre 2003. Milano, Electa Publ., 2006, pp. 135-145 (in Italian).

24. Kadığlu M.; Görkay K.; Mitchell S. Roman Ancyra. Istanbul, Yapı Kredi Publ., 2011. 280 p.

25. Kaegi W. E. Heraclius: Emperor of Byzantium. Cambridge, Cambridge University Press Publ., 2003. 359 p.

26. Krischen F.; Lüpke T. von; Meyer-Plath B.; Schneider A. M. Die Landmauer von Konstantinopel. I-II, Vol. 66. Berlin, de Gruyter Publ., 1938 (in German).

27. Leader R.E. The David plates revisited: transforming the secular in Early Byzantium. The art bulletin, 2000 , no. 82, pp. 407-427.

28. Macridy T., Casson S. Excavations at the Golden Gate, Constantinople. Archaeologia, 1931, no. 81, pp. 63-84.

29. Magdalino P., The distance of the past in early medieval Byzantium (VII-X centuries). Ideologie e pratiche del reimpiego nell'Alto Medioevo, Atti della XLVI Settimana CISAM. Spoleto, la Sede del Centro Publ., 1999, vol. I, pp. 115-146 (in Italian).

30. Magdalino P. Constantinople médiévale: études sur lévolution des structures urbaines. Paris, de Boccard Publ., 1996. 117 p. (in French).

31. Magdalino P. The "columns" and the Acropolis gate: a contribution to the study of the ceremonial topography of Byzantine Constantinople. Philopation. Spaziergang im kaiserlichen Garten. Schriften über Byzanz und seinen 
Nachbarn. Festschrift für Arne Effenberger zum 70. Geburtstag. Mainz, Verlag des Römisch-Germanischen Zentralmuseums Publ., 2012, pp. 147-156 (in German).

32. Mamboury E. Ankara. Guide touristique. Ankara, Ministère Turc de l'Intérieur Publ., 1933. 314 p. (in French).

33. Mango C. Antique Statuary and the Byzantine Beholder. Dumbarton Oaks Papers, 1963, no. 17, pp. 55-75 (reprinted in Mango C. Byzantium and its Image. History and Culture of the Byzantine Empire and its Heritage. Aldershot, Variorum Reprints Publ., 1984, no. V).

34. Mango C. The Triumphal Way of Constantinople and the Golden Gate. Dumbarton Oaks Papers, 2000, no. 54, pp. $173-188$.

35. Müller-Wiener W. Spoliennutzung in Istanbul. Beiträge zur Altertumskunde Kleinasiens. Festschrift für Kurt Bittel. Meinz am Rhein, von Zabern Publ., 1983, pp. 369-382 (in German).

36. Naumann R. Neue Beobachtungen am Theodosiusbogen und Forum Tauri in Istanbul. Istanbuler Mitteilungen, 1976, no. 26, pp. 117-141 (in German).

37. Niewöhner P. Byzantine city walls in Anatolia. From status symbol to the bulwark against the Arabs. Neue Forschungen zu antiken Stadtbefestigungen im östlichen Mittelmeerraum und im Vorderen Orient. Byzas Publ., 2010, no. 10, pp. 239-260 (in German).

38. Papalexandrou A. Memory Tattered and Torn: Spolia in the Heartland of Byzantine Hellenism. Archaeologies of Memory. Malden - Oxford - Victoria - Berlin, Blackwell Publ., 2003, pp. 56-80.

39. Baldini I.; Cosentino S. (ed.). Potere e politica nell'età della famiglia teodosiana (395-455): i linguaggi dell'impero, le identità dei barbari. Bari, Edipuglia Publ., 2013. 264 p. (in Italian).

40. Restle M. s.v. Ankyra. Reallexikon zur byzantinischen Kunst, I. Stuttgart, Hiersemann Publ., 1966, pp. 170-177 (in German).

41. Ricci A. Ut scultura poesis: statuaria classica nelle dimore costantinopolitane di età tardoantica e bizantina (IV-X secolo). Medioevo: il tempo degli antichi, Atti del Convegno internazionale di studi. Parma, 24-28 settembre 2003. Milano, Electa Publ., 2006, pp. 188-196 (in Italian).

42. S.v. Herakles. Lexicon iconographicum mythologiae classicae, IV-V.1. Zürich-München, Artemis \& Winkler Verlag Publ., 1990 (in German).

43. Saradi-Mendelovici H. Christian Attitudes toward Pagan Monuments in Late Antiquity and Their Legacy in Later Byzantine Centuries. Dumbarton Oaks Papers, 1990, no. 44, pp. 47-61.

44. Scheer T. S. Pagan past and christian presence. Die Kultbilder der Götter in der Spätantike. Epochenwandel? Kunst und Kultur zwischen Antike und Mittelalter. Mainz, von Zabern Publ., 2001, pp. 36-44 (in German).

45. Serin U. La cittadella di Ankara dopo de Jerphanion. Problemi di conservazione e proposte per il recupero urbano. Mélanges de l'Ecole Française de Rome. Moyen âge, 1998, no. 110, 2, pp. 953-970 (in Italian).

46. Serin U. Late Antique and Byzantine Ankara. Topography and Architecture. Marmoribus vestita. Miscellanea in onore di Federico Guidobaldi. Città del Vaticano, Pontificio Istituto di Archeologia Cristiana Publ., 2011, pp. 1257-1280 (in Italian).

47. Spolia in Late Antiquity and the Middle Ages - Ideology, Aesthetics and Artistic Practice. Hortus artium medievalium, 2011, no. 17. 314 p.

48. Mitchell S.; French D. (eds.). The Greek and Latin Inscriptions of Ankara (Ancyra). From Augustus to the end of the third century AD. Vestigia, vol. 62. München, Verlag C. H. Beck Publ., 2012. 523 p.

49. Sir Thomas Roe. The Negotiations of Sir Thomas Roe in His Embassy to the Ottoman Porte. London, 1740.150 p.

50. Weitzmann K. Greek Mythology in Byzantine Art. Princeton, Princeton University Press Publ., 1951. 218 p. 